\title{
FROM THE HISTORY OF THE STUDY OF MATERIAL CULTURE OF THE KARAKALPAK PEOPLE
}

\author{
Taghbayev Amirbek Ashirbayevich
}

Deputy Dean At The Faculty Of Pharmacy, Tashkent Pharmaceutical Institute Tashkent, Uzbekistan

\section{ABSTRACT}

This article discusses the history of the study of the material culture of the Karakalpak people. Kara, Balykchi, Beshkum, Kazanketgan, Qum-uzak in the Ustyurt plain are among the largest settlements with real and mobile housing in the middle of the XVIII-XIX centuries. In the XVIII and XIX centuries, on the southern shores of the Aral Sea, in the Tollik and Beshkum and again in the Shamishkol Uzun-Kair-Tilla oases, the Karakalpaks lived a semi-sedentary lifestyle and engaged in cattle-breeding, hunting, and fishing with the Kazakhs. engaged in obtaining dyes from plants. The central cities of Karakalpakstan where trade was developed were: Chimbay, Kungrad, Khojaly.

KEYWORDS: - Balykchi, Beshkum, Kazanketgan, Qum-uzak, Ustyurt, Tollik, Beshkum, Karakalpaks, Chimbay, Kungrad, Khojaly, archaeological materials, Aral Sea region, traditional housing, Turtkul district.

\section{INTRODUCTION}

Archaeological materials serve to describe the way of life of the people of the Aral Sea region and help to consider the evolution of traditional housing of the Karakalpaks. In the territory of Karakalpakstan, especially in the Turtkul district, samples of wooden and reed parking lots and houses of the so-called Kaltaminor culture were found [1.32].

Archaeological excavations have uncovered about 30 Mesolithic and Neolithic settlements in the northwestern part of the Ustyurt Plain (1977-1979). Ancient dwellings, such as Kozalikir kala and Bazar kala, have also been found. Yambash-kala, Koykyrilgan kala and others are among the monuments of Qangu culture. They consist of fixed rectangular structures, multi-room apartment blocks divided into two main neighborhoods.

Ayaz-kala 3, the open middle layer of the Toprak kala, belongs to the Kushan culture. During this time many large family courtyards with no interior walls began to appear. Large ethnic settlements have been preserved in the forts. The Kushan-Afrigid culture is characterized by tower-type dwellings, the inner walls of which are made of cotton and have brick granaries in the center or citadels in the courtyard. The ancient Aybuyur kala, located $41 \mathrm{~km}$ north-west of Shumanay, was studied by M. Mambetullayev, and the ancient settlements on the right bank of the Amudarya were studied by Y. Nerazik [2.256]. Medieval appliances, building materials, and housing planning are reminiscent of the traditional Karakalpak homes of the early XIX and early XX centuries. This is especially confirmed by the data of the Janpiqkala excavations [3.111;70-75;100;291-297]. 
CURRENT RESEARCH JOURNAL OF HISTORY 2(9): 36-44, September2021

DOI: https://doi.org/10.37547/history-crjh-02-09-10

ISSN 2767-472X

(C)2021 Master Journals

\section{Crossref do) 81 Google}

Accepted 25 $5^{\text {th }}$ September, 2021 \& Published 30th September, 2021

\section{THE MAIN FINDINGS AND RESULTS}

Written sources about ancient medieval castles, the settlements of the peoples of the South Aral Sea, and their homes are known from the data. Herodotus gave information about the Scythian settlements [4.74-75]. Excerpts from similar information are also found in the works of Arab authors. For example, the tenth-century historian Ibn Fadlan writes: "There is a black house made of Turkish felt inside, not in the middle of the house" [5.123]. Maybe it's a house (a black house built for living). This tradition of real estate has survived to this day.

It should be noted that not all the information is true. For example, according to the Arab geographer Yakubi (IX century), in the Turkic peoples "There are no strong habitats, they live in Turkish tents with ribs, where instead of nails they use threads made of animal and cow skins and cover them with felt".

In the 13th century, European ambassadors and travelers wrote about the settlements of the Turkic-Mongol peoples and the peoples of the Aral Sea region. According to Plano Carpini: "They are collected from walls made of thin sticks, and there are varieties that are not assembled. They will be moved in carts" [6.2728]. In the XIV century, Rashid al-Din gave information about the Turkic-Mongol peoples by naming them Nukus, Kiyat, Kipchak, Kangli and other ethnonyms. It is said of the dwellings of these people, "Light came in through the smoke of the tabernacle" [7.81-152]. Jenkinson, an English merchant in the Lower Amu Darya in 1558: “...I stopped at a small round house made of reeds, covered with felt on the outside and carpeted on the inside" [8.175].

In the XVII and XVIII centuries, settlements and numerous black houses could be found on the shores of the Aral Sea. There is only information about.
Documents of the Russian Empire, the first maps of Central Asia show the areas inhabited by the Karakalpaks, A. Tevkelev's research reveals ethnographic data about the Karakalpaks [9.6]. In the documents of Dmitry Gladishev, a soldier who traveled from Orsk to Khiva in 1740-1741, and Muravin, a surveyor, we have information about the location and settlement of the Karakalpaks on both sides of the Syrdarya, Kuvandarya and Adam, and their occupation [10.71-72]. P. Richkov's "Topography of the Orenburg Province" contains chapters on the history and ethnography of the Karakalpaks. Valuable but fragmented information about the life of the Karakalpaks can be found in the historical chronicles of Munis and Ogahi [11.69117]. The documents of the archives of the Khiva khans contain the names and ethnic composition of the settlements in the lower Amudarya, information on tax collection.

Kara, Balykchi, Beshkum, Kazanketgan, Qumuzak in the Ustyurt plain are among the largest settlements with real and mobile housing in the middle of the XVIII-XIX centuries. In the XVIII and XIX centuries, on the southern shores of the Aral Sea, in the Tollik and Beshkum and again in the Shamishkol Uzun-Kair-Tilla oases, the Karakalpaks lived a semi-sedentary lifestyle and engaged in cattle-breeding, hunting, and fishing with the Kazakhs. engaged in obtaining dyes from plants. The central cities of Karakalpakstan where trade was developed were: Chimbay, Kungrad, Khojaly.

P.N. Danilevsky gave some information about the Lower Amudarya Karakalpaks. He wrote that they ran a collective farm, engaged in farming, animal husbandry, fishing, and in the summer moved to small meadows and lived in pastures, so they were called nomadic peoples. Analyzing P.N. Danilevsky's opinion, he gave only information about the northern districts of Karakalpakstan [11.69-117]. 
CURRENT RESEARCH JOURNAL OF HISTORY 2(9): 36-44, September2021

DOI: https://doi.org/10.37547/history-crjh-02-09-10

ISSN 2767-472X

(C)2021 Master Journals

\section{Crossref dof 81 Google}

Accepted 25th September, 2021 \& Published 30 th September, 2021

On May 15, 1858, Robert Yakovlevich Kileveyn set out from Orenburg on the Ilek and Emba rivers on a mission to explore the regions and riches of Central Asia, from the western shores of the Aral Sea to Lake Aybuyur. He identified the houses with mud walls and gardens next to the real houses located in the territory of Kungrad district [12.3-4].

P. Nebolsin noted that in Ustyurt - Kurgan, Akbulak, Koshbulak, Urga, Karaumbet and other places there are real and mobile homes [13.10]. M.N. Galkin, who lived in the lower Amudarya region in 1858-1859, also spoke about the sedentary life of the Karakalpaks, about their mobile and immovable houses, and about the narrow streets and covered roofs in Kungrad. There were houses with terraces, and the lawns gave information that there was a garden next to it. It was all in one wall. M. N. Galkin noted that Kungrad was once surrounded by a wall near the river. Only the remains of them remain. Between Kungrad and Khojaly there was the Nukus Fortress, then in the cities of Khojaly and Kipchak there were mosques, madrasas, mobile and immovable dwellings, winter and summer settlements places [14.177-185]. According to A. Butakov, the Karakalpaks were only engaged in agriculture, but lived in the grasslands and were protected in a mud city when the enemy invaded them (town).

Hungarian scholar Arminius Vamberi, who went to Khiva and then to Bukhara in 1863 (then Jewish), gave some information about the culture and economy of the Karakalpaks. Translation A. I. Pavlovskogo. Toma I-II. - St. Petersburg: 1873. named). In particular, the villages of Tuyamoyin, Aqkamish, Kalandarkhanas (in Turtkul district) and the address of Sultan Uvays in Beruni district provided information about this. Shorakhon is surrounded by a mud wall. The gate is open twice a week for trade. The calendar is located in front of the city gate, and next to it is a black house [15.124-128]. A. Vamberi gives information about the remains of China, Kipchak, Rahmonberdi-biy (formerly Biybozor), Mangit, Nukus, Khojayli, Yampik, several mosques and madrasas, Kobilbeklarbegi yard. The black houses of the lower Amudarya peoples were similar to the black houses of the "Kyrgyz", but without ornaments and the upper ones were covered with leather. A. Vamberi's research on black houses does not correspond to any information about the first half of the XIX century, that is, the houses of the Karakalpaks were never covered with skin, the black houses of the rich Karakalpaks were distinguished by their equipment.

After the conquest of the Khiva Khanate by Russia, the study of its economy and people became more widespread. It was carried out for short practical purposes: on the one hand, on the basis of Russia's production and trade in Central Asia, and on the other hand, on the basis of military administration. The culture of the Khiva khanate's dependence on Russia is connected with historical research. From 1873 a number of data on the Khiva khanate organized scientific expeditions in various forms. The Russian Geographical Society provided materials for the members of the expedition to study. A. Kun, A. Kaulbars, N. Karazin, L. Kostenko, I. Krause conducted their research on this topic.

A. Kun studied the ethnographic and statistical aspects of the distance from Khiva to the Aral Sea. A. Kaulbars studied the lower reaches of the Amudarya. According to A. Kun, on the shores of the Aral Sea lived a semi-settled population of Karakalpaks. The ancient inhabitants of Nukus, who gave information about their way of life (sedentary and semi-sedentary), the lakes, say that most of the inhabitants lived in the north and northwest [16.203-254]. In 1876, A. Kun wrote in an article that the old irrigation canals, the settlement (Kilichniyozboy, Maylishengil) (now Amudarya district), the historical monuments between Old Urgench and Khojayli, 
CURRENT RESEARCH JOURNAL OF HISTORY 2(9): 36-44, September2021

DOI: https://doi.org/10.37547/history-crjh-02-09-10

ISSN 2767-472X

(C)2021 Master Journals

\section{Crossref dof 81 Google}

Accepted 25th September, 2021 \& Published 30 ${ }^{\text {th }}$ September, 2021

for example, Shomunabi, Goya kala, Karakul, Aybuyur fortress, etc. have been studied. The town of Khojaly is located on the bridge that connects the two banks of the Suenli Canal, with markets on either side. According to A. Kun, the name of Khojayli is connected with the name of Khoja from Turkestan. A. Kun Khojayli admits that the historical monuments between Kungrad and Kungrad-Chimbay were inhabited by Karakalpaks from Kuskhanatau to Chimbay.

A. Kaulbars studied the Amudarya delta and mapped it, where you can see the settlements. It serves as an important source for us to study the habitats of Karakalpaks, especially in Nukus, Kipchak, Beltau. The Karakalpaks on the outskirts of Beltau are engaged in fishing and animal husbandry, but each family is also involved in farming. According to Kaulbars, Yanasu's water flowed from Lake Dauqora to the sea. The upper reaches of the Janadarya are called Kokkol, where Karakalpak villages are located. Water came to the canals from Kokkol by means of ditches. On the left bank of the Janadarya was the city of Mexter. According to locals, the city of Janibek has existed since the 60 s of the XIX century. Barley fields in the lower reaches of the Kokozak, and a waterfall in the southern part of Kuskhanatau to Shurtanbay, around which the Karakalpak population lived. To the south of Tok Castle are mud houses, cemeteries, and water from the Tarli Canal to the town of Kangli Bek-Eshan.

According to A. Butakov and A. Kaulbars, the city of Nukus is located on the right side of the Karabayli canal. In turn, he acknowledged the fortress of Aqqala. In the central part of Tollyk there are the ruins of Mulla-pirim, 4-5 km below (Toshpolat-axun). The ruins of Kulman kala are located on the $3 \mathrm{~km}$ left bank of the Qiyot-Bugit pass. Not far from it is the Azbergen kala. A. Kaulbars explains the differences between the black houses of Karakalpaks and Kazakhs. It also emphasizes the interiors of the black houses of the Karakalpaks [17.33-49;76-77]. In particular, according to him, the location of the Karakalpak people and most of their farms have disappeared.

According to N. Karazin, in rural areas Karakalpaks lived in a state of gypsum, that is, in their lands there were tools and livestock, etc. He refutes the earlier scholars' claim that pastures, arable land, and tools were used by their people. According to him, the Karakalpaks had seasonal houses, that is, houses for fishermen (pavilions).

N. Karazin clearly shows the location of the cities of Kuskhanatau and Chimbay, which can be seen from arable lands, wintering grounds, permanent and mobile houses (black houses), where the population lived in gypsum. The Karakalpaks covered their black houses with felt and the side walls with woven straw [18.198-203]. There were summer houses for the Karakalpaks, and next to them were houses built for winter living, which were high-walled houses made of square clay and with attics on the inside.

According to A. Karazin, the city of Chimbay was the administrative center, where there were public buildings, markets and streets. The Chimbay market was covered with hanging umbrellas. Their ropes were tied to the roofs of houses. These closed scenes were spread all over the market. There are few houses in Chimbay, and the city is made of cotton walls and is about $1.5 \mathrm{~km}$ long. Only the market area was built there. In the summer, the Karakalpaks moved around their fields with their black houses, and in the winter, they came to Chimbay, where up to 40,000 black houses would gather. Including Khojaly, Kungrad, Nukus, etc. These were located along the canal and formed the administrative centers. There was also the village of Nukus around the city of Nukus. Near the Chilpik Pass there is the Khojaniyazbi Madrasah, which has a crescent-shaped dome made of baked bricks and was built in the late XVIII century. Later, according to N. Karazin, Biybozor, Shabboz vali, 
CURRENT RESEARCH JOURNAL OF HISTORY 2(9): 36-44, September2021

DOI: https://doi.org/10.37547/history-crjh-02-09-10

ISSN 2767-472X

(C)2021 Master Journals

\section{Crossref do) 81 Google}

Accepted 25th September, 2021 \& Published 30 th September, 2021

Shorakhon, they consisted of permanent and mobile houses. The khan's palace was located in Shabboz Walli, and its walls consisted of angular towers and narrow burglars, which were later converted into caravanserais. The ruins of the fort were located 19-20 kilometers from Shabboz Wali, and according to legends, it was built before the Arab conquest. According to Karazin, fishermen gather at the same time on permanent and mobile farms. The semi-settlement represents the way of life of the local people, including the Karakalpaks. In another of $\mathrm{N}$. Karazin's works, he admits that they were located on the banks of the Aqqala and Ulken river rivers, which is known from the Russian invasions of 1875 . The houses of the village mullahs were more beautiful than the others, and there was no information about the interior decoration of their houses. According to him, the black houses of the Urals and local Karakalpaks at the confluence of the river, the lifestyle of the Karakalpaks and Kazakhs in the lower reaches of the river (lower Syrdarya) are compared. N. Karazin noted that it is located around the herdsmen's cattle. You can tell from the houses here that they lived there [19.688-690]. It is the location of the Karakalpaks, the main settlements of the Karakalpaks in the Kok Darya region, i.e in the northern part of the Karaozak district, such as Ayrisha, Mergenatau, Termenbes, Jalair and others. There are developed relations with neighboring peoples in trade, handicrafts and farms.

According to L. Kostenko, it is located $16 \mathrm{~km}$ (2.5-3 km) from the right bank of the Amudarya with the population of the White Fortress. They consisted of several tribes. The castle was empty at that time and was occupied by the inhabitants of the town. The castle had a rectangular shape and a tower. It served as a strategist for the protection of the northern borders of the Khiva Khanate [20.163-164].

In 1873, Krauze, a member of the Amudarya expedition, wrote that the Karakalpaks planted trees as building materials and for food, and that the natives did not pay much attention to reforestation because they did not need forests.

In the work of P. Veselovsky the written sources from the time of Al-Beruni to the end of the XVIII century are generalized. He also mentions the presence of Kerder, Mizdahkon, Kungrad, Shakhtemir (Chimbay) and other large settlements in the Khiva khanate, along the Aral Sea [21.364].

The territory of Karakalpakstan, which passed to Russia in 1875-1913, was studied several times for military and social purposes. As a result, a lot of material on Karakalpak ethnography has been collected. The collected materials are an important source for studying the economic location and settlements, tribal composition and social structure of the Karakalpaks. According to the study of nomadic and sedentary local economy and land use of the Amudarya branch of the Syrdarya region, settlements, madrasas located along the river, the tribal composition of the Karakalpaks, their types of farming, general information on the total number is given [22.83]

In 1902, A. Y. Rossikova published in the journal Russian Vestnik the materials of her travels along the Amudarya. He built mosques and madrasas from Petro-Alexandrovsk to Nukus, settlements, types of farms, the city of ShokhAbboz and its stone and baked brick minaret, the tomb of Sultan Bobo, Yampik Qala, the tomb of Salomat Bobo, Orazimbet, the descriptions described around the Hak Mountain, and the legends associated with these historical monuments are recorded. These legends are reminiscent of the legend of the prophet Shamun.

The literature provides incomplete information about the customs and beliefs of the Karakalpaks associated with the place. In particular, accommodation should be open, dry, clean and above ground level. 
CURRENT RESEARCH JOURNAL OF HISTORY 2(9): 36-44, September2021

DOI: https://doi.org/10.37547/history-crjh-02-09-10

ISSN 2767-472X

(C)2021 Master Journals

\section{Crossref dof 81 Google}

Accepted 25th September, 2021 \& Published 30 ${ }^{\text {th }}$ September, 2021

A flock of sheep was sent to kill all the venomous spiders in the area before planting [23.224]. To ward off evil spirits, the godly Karakalpaks used various amulets, such as animal horns and other things.

After joining Russia, information about the settlements and homes of the Karakalpaks was partially stopped in reports and descriptions. For example, the general housing plan, it should be noted, is one-sided in all of these sources, the lack of data, the lack of special research on the ethnography of the Karakalpaks, in particular the Karakalpaks, their habitats and housing. We can see that there is no data. The work of the participants of the scientific expeditions of the late XIX and early XX centuries has little and incomplete information on the subject of our research. The main purpose of such expeditions was not to study the ethnography of the peoples of the lower reaches of the Amu Darya, but only to gather information to manage the occupied territories.

Linguistic research of Karakalpaks in the 1920s was studied by N.A. Baskov and A.S. Morozov. From 1928 to 1929, Karakalpak expeditions in Karakalpakstan worked to study Kazakhstan, where A.L. Melkov photographed mobile black houses and outbuildings, and the process of building black houses (A. L. Melkov organized an expedition to Kazakhstan in 1927, led the Karakalpak expedition from 1927 to 1928, and several photographs he took in the field at the time: his own horse and a collective photograph of the expedition members have survived. Frame 20-21, 23.40, 37, 61, 65, 92, 100. [MAE, coll. I 1381-324,331]. The results of two years of field research were presented in two collections (the first to the Museum of Local Lore in Turtkul, then the capital of the Karakalpak Autonomous Region, the second to the ethnographic department of the Russian Museum (now REM, col. 5111), and more than seven hundred photographs to the Museum of Anthropology and
Ethnography). given to the illustrative fund of the Central Asian branch). During these years, S.P. Tolstov conducted field ethnographic work in eastern Turkmenistan and Karakalpakstan. (Old Urgench and Khojayli districts). From 1932 to 1934, S.P. Tolstov led an expedition to the People's Museum, which collected various information from the traditional settlements of the Karakalpaks. In 1928, G.K. Schuls, a member of the Central Asian expedition, found the wooden remains of a black house in the Chimbay district, which are kept in the fund of the People's Ethnographic Museum in St. Petersburg [24.31].

In 1927, A.S. Morozova began the first ethnographic work, during which she studied the culture of the Karakalpaks, and continued her research until 1958. On the basis of these collected materials in 1958 he defended his dissertation on Karakalpak culture and way of life of the XX century, the second chapter of which provides information about their traditional settlements [25.58-97]. According to A.S. Morozova, the mobile homes of the Karakalpaks appeared in the late 19th and early $\mathrm{XX}$ centuries, and were no different from the houses of Uzbeks.

In 1945, the Karakalpak ethnographic group of the Khorezm expedition conducted a systematic tour of the ethnographic study of the Karakalpaks under the leadership of T.A. Zhdanko (Deputy Head of the Khorezm Archaeological Expedition, currently appointed head of the Department of Ethnographic Research). The members of this group collected materials and published articles, which are now stored in the Institute of Ethnology and Anthropology of the Russian Academy of Sciences, the Institute of History, Archeology and Ethnography of the Karakalpak branch of the Uzbek Academy of Sciences.

T.A. Zhdanko studied the system of tribes and 
CURRENT RESEARCH JOURNAL OF HISTORY 2(9): 36-44, September2021

DOI: https://doi.org/10.37547/history-crjh-02-09-10

ISSN 2767-472X

(C)2021 Master Journals

\section{Crossref dof 81 Google}

Accepted 25th September, 2021 \& Published 30 ${ }^{\text {th }}$ September, 2021

drew a map of their location [26.96-132]. The research will include information on Karakalpak mobile homes, their construction plans, what building materials they used, how they were built, and the assembly of black houses. He believes that the black houses of the Karakalpaks are different from other peoples in the region in terms of their construction. In the book "Peoples of Central Asia and Kazakhstan" in the "Karakalpak" section of the chapter "Peoples of the World" T.A. Zhdanko gives a brief information about the place of residence and location of the Karakalpaks. He provides valuable information on the study of Karakalpak handicrafts in his article "Karakalpak Folk Crafts". He described many of these crafts for the first time and gave an overview of the Karakalpak people.

Members of the ethnographic group of the Khorezm expedition S.K. Kamolov, R. Kosbergenov, V. Shalekenov published historical ethnographic works [27.137-138]. In the subsequent works of R. Kosbergenov, opinions were expressed on the subject in the opposite context [28. 298-323] In his monograph S.Kamalov gave information about the way of life and culture of the Karakalpaks in the XVIII-XIX centuries, winter and summer settlements, fortifications [29.83-84]. In her scientific works L.S. Tolstova provided information about the traditional habitats of Karakalpaks in the Amudarya, Bukhara and Samarkand regions of the Republic of Uzbekistan [30.112-138] A.Utemisov's research is devoted to the study of fishermen's culture, different habitats and their contents [31.47-51] K. Ametov's memoirs describe the Karakalpak settlements and courtyards in winter and summer [32.5-16]. A team work was published in 1980, one chapter on the location and location of the Karakalpaks in the early 19th and early XX centuries, the author $H$. Esbergenov described the settlements near the Amudarya, all the details of the black houses.
Unfortunately, there is no information about the size of Karakalpak black houses [33.32]. K. Saribayev's monograph describes the history of irrigation in Shumanay, Kegeyli and other villages. In his book "Ethnographic History of Karakalpakstan" K. Mambetov briefly describes the wooden places brought by the nomads of the Black House in Central Asia, the wooden places and the patterns inside. K.Mambetov explains the difficulty of the master in the construction of the door of the black house in comparison with other places in the construction of the black house [34. 95-98].

\section{Conclusion}

Karakalpak folklore, such as "Kirkkiz", "Alpomish" and other epics, about the traditional way of life. The protagonist of the epic "Forty Girls" is Guloyim, who builds a fortress on the Aral Sea and lives in a black house with forty girls. The epic "Alpomish" is about the sedentary life. Berdakh's works "Mastposhsha" and "Shajara" is about the Karakalpak black house and its construction. Another prominent figure in Karakalpak literature, Kunkhoja Ibrahim (1799-1880), in his poem "Jaylaum", says that he moved from the Kok-Darya due to lack of water. Traditional habitats are given in Karakalpak narratives, especially about black houses. For example, in the form of questions and answers are given about the objects of the black house, its names and its construction, and so on.

\section{ReFERENCES}

1. Tolstov S.P. Ancient Khorezm. - Moscow: Moscow State University, 1948. - P. 32.

2. Nerazik E.E. Rural dwelling of Khorezm (IXIV centuries). - Moscow: "Science", 1976. - P. 256.

3. Kdyrniyazov M.-Sh. The history of the material culture of the cities of Khorezm in 
CURRENT RESEARCH JOURNAL OF HISTORY 2(9): 36-44, September2021

DOI: https://doi.org/10.37547/history-crjh-02-09-10

ISSN 2767-472X

(C)2021 Master Journals

\section{Crossref do) 81 Google}

Accepted 25 $5^{\text {th }}$ September, 2021 \& Published 30th September, 2021

the XIII-XIV centuries. - Nukus: Karakalpakstan, 1989. - P. 111. Dospanov O.T. On some of the results of the excavations of Dzhanpyk Kala in 19871989. // New discoveries in the Aral Sea region. - Moscow: 1991. Issue 2. - P. 70$\neg 75$; Its the same. Zhampyk kala is a monument of the Middle Ages. - Nukus: "Karakalpakstan", 1992. - 100 p; Dospanov O.T., Torezhanova N.Zh. On the study of metal products from the Dzhanpyk kala settlement // IMKU. - Samaraand, 1999. Issue. 30. - P. 291-297.

4. Herodotus. History.,1972. - P. 74-75.

5. Kovalevsky A.P. Book of Akhmed ibnFadlan about his journey to the Volga in 921-922. - Kharkov, Ukraine,1956. - P. 123.

6. Plano Carpini History of the Mongols / Per. A.I. Maleina. - In the book: Plano Karpina J. History of the Mongols. Rubruk G. "Travel to the eastern countries". - Moscow:1957. P. 27-28.

7. Rashid-ad-din. Jome'at-tavorix,1952, P. 81152.

8. Bratianu A. Actes des notaries qenois de Pera et de Coffa de Ia Sindu XII SiecIe. Bucarest, 1937. - P. 175.

9. Ethnography of the Karakalpaks of the 19 th - early 20 th centuries (materials and research). - Tashkent: 1980. - P. 6

10. A trip from Orsk to Khiva and back, made in 1740-1741 by Lieutenant Gladyshev and geodesist Muravin. St. Petersburg. 23 april 1851. - P. 71-72.

11. N.Ya.Danilevsky On the movement of population growth in Russia. - SPb., 1851, P.-69-117

12. Robert Yakovlevich Kilevain in 1856-1860 identified houses with mud walls and gardens next to real estate in the Kungrad district. - St. Petersburg. 1862. P. - 3-4

13. Nebolsin P.I. Essays on Russia's trade with Central Asia. - Moscow,1856, P.-10

14. Galkin M.N. Ethnographic and historical materials on Central Asia and the Orenburg region. - SPb., 1868, P.177-185

15. Vamberi A. Travels in Central Asia. Moscow, 1867, P.-124-128

16. Kun A. L. Culture of the oasis in the lower reaches of the Amu Darya // MSTK. - SPb., 1886. Issue-IV. - P. 203-254.

17. Kaulbars A.V. The lower reaches of the Amu-Darya, described according to his own research in 1873, Notes of the IRG0, 1881, P. 33-49;76-77.

18. Karazin N. In the distant outskirts. - St. Petersburg, 1875, P. 198-203.

19. Karazin N. In the distant outskirts. - St. Petersburg, 1875, C. 688-690

20. Kostenko L. On the study of the old channel of the Amu Darya. // "Military collection”.1873, № 11-12. 1873. P. 163164.

21. Veselovsky N. Essay on historical and geographical information about the Khiva Khanate from ancient times to the present. - SPb: 1877. - P. 364.

22. Materials on the survey of nomadic and sedentary indigenous households and land use in the Amudarya department of the Syrdarya region. -Tashkent:1915, P.-83

23. Asian Russia. Sat. st. 2nd ed. M., 1905. Comp. A. Kruber and others, P. 224.

24. Ethnography of the Karakalpaks of the 19th - early 20th centuries (materials and research). - Tashkent: 1980. -P. - 31

25. Morozova A.S. The culture of home life of 
CURRENT RESEARCH JOURNAL OF HISTORY 2(9): 36-44, September2021

DOI: https://doi.org/10.37547/history-crjh-02-09-10

ISSN 2767-472X

(C)2021 Master Journals

\section{Crossref do) 81 Google}

Accepted 25 $5^{\text {th }}$ September, 2021 \& Published 30 ${ }^{\text {th }}$ September, 2021

the Karakalpaks at the beginning of the twentieth century (On the issue of ethnogenesis). : Abstract dissertation .... Cand. ist. sciences. Tashkent:1954. - P. 5897.

26. T.A. Zhdanko Essays on the historical ethnography of the Karakalpaks. Leningrad: - 1950. P. - 96-152.

27. Kamalov S. Liberation Struggle. - People's liberation struggle of the Karakalpaks against the Khiva khans in the 19th century, "Materials and research on the ethnography of the Karakalpaks", Moscow: 1958 (TKHAEE, III)-P.137-138.

28. Kosbergenov R. Situation of the Karakalpak population in the Khiva Khanate in the late XIX - early XX centuries, - "Materials and research on the ethnography of the Karakalpaks" Moscow: 1958 (TCAEE, III), p. 298-323.

29. Kamalov S.K. Karakalpaks in the 18th-19th centuries: On the history of relations with Russia and the Central Asian khanates. Tashkent: "Science" 1968. - P. 83-84.

30. Tolstova L.S. Karakalpaks of the Fergana Valley. - Nukus, 1959. - pp. 38-43, Karakalpaks outside the Khorezm oasis in the XIX - early XX century. - NukusTashkent,1963. - P. 112-138.

31. Utemisov A. Life and culture of fishermen on the coast of the Southern Aral (Late XIX - 60s of the XX century). Abstract dissertation .... Cand. ist. sciences. Chimbai, 1970. - 25, P. 47-51

32. Ametov K. From the history of the main forms of land tenure among the Karakalpaks of the Khiva Khanate (from the 2nd half of the XIX century to 1920), "Vestn. Karakalpak branch of the Academy of Sciences of the Uzbek SSR", Nukus, 1961, № 4, P. 5 - 16.
33. Ethnography of the Karakalpaks of the XIX - early XX centuries (materials and research). - Tashkent, 1980. - P. - 32

34. K.Mambetov Karakalpak tolgaular. Nukus, 1995, P.-95-98

35. Berdaq. Pedigree- Nukus,1977. - P. 10. 